\title{
The effect of urea fertilizer doses on the chemical characteristics of the Samurai- 1, Samurai-2, and Pahat mutant sorghum (Sorghum bicolor L.) grain varieties
}

\author{
1,*Kurniadi, M., ${ }^{2}$ Nurcholis, M., ${ }^{2}$ Roeslan, M., ${ }^{2}$ Widodo, R.A., ${ }^{1}$ Wiyono, T., ${ }^{1}$ Rosyida, V.T, \\ ${ }^{1}$ Nurhayati, R., ${ }^{1}$ Kusumaningrum, A. and ${ }^{3}$ Human, S. \\ ${ }^{1}$ Research Unit for Natural Product Technology, Indonesian Institute of Sciences (BPTBA LIPI) \\ Gunungkidul, Yogyakarta, Indonesia \\ ${ }^{2}$ The Agriculture faculty of the University of National Development of "Veteran" Yogyakarta, Indonesia \\ ${ }^{3}$ Center for the application of Isotope and Radiation Technology, National Nuclear Energy Agency of \\ Indonesia (BATAN), Jakarta, Indonesia
}

\begin{abstract}
Article history:
Received: 1 September 2020

Received in revised form: 15 October 2020

Accepted: 30 November 2020 Available Online: 21 March 2021
\end{abstract}

\section{Keywords:}

Sorghum,

Mutant variety,

Urea fertilizer,

Chemical characteristics

DOI:

https://doi.org/10.26656/fr.2017.5(2).475

\begin{abstract}
This research aimed to determine the influence of various doses of urea fertilizer on the chemical characteristics of mutant sorghum (Sorghum bicolor L.) grain varieties Samurai1, Samurai-2, and Pahat. A Fully Randomized Factorial Design was used by employing two factors and three replications. The three varieties of mutant sorghum grain served as the first factor while four doses (i.e., 0, 30, 60, and $90 \mathrm{~kg} / \mathrm{ha}$ ) of urea fertilizer administration served as the second factor. The parameters in the chemical test on the sorghum grain include ash, total protein, amylum, reducing sugar, dissolved protein, and tannin contents. The administration of urea fertilizer significantly influenced the increase in the ash, amylum, reducing sugar, and dissolved protein contents of Samurai-1 but did not significantly do so to such contents of Samurai-2 and Pahat. The urea fertilizer dose of $90 \mathrm{~kg} / \mathrm{ha}$ gave the best results of the chemical composition of the three types of mutant sorghum grain. Chemically, mutant sorghum flour of the three varieties is qualified as a quality food ingredient with Samurai-1 being the best of the three varieties, in that case, possessing total protein content of $7.90 \%$, amylum (or starch) content of $14.51 \%$, dissolved protein content of $2.38 \%$, reducing sugar content of $2.88 \%$, and tannin content of $0.70 \%$.
\end{abstract}

\section{Introduction}

Sorghum (also known as Sorghum bicolor L.) has great potential for being grown in Indonesia because of its wide adaptability and high productivity. Sorghum is not a native Indonesian plant species so that its genetic variability in Indonesia is low and the development of programs for its improvement, in that case, is required to support the development of national sorghum (Human, 2010).

Research on the use of sorghum as food has been considerably done by many scientists (Suarni and Singgih, 2002; Sirappa, 2003; Awika and Rooney, 2004; Earp et al., 2004; Awadalkareem et al., 2008; Setiarto and Widhyastuti, 2016; Kurniadi et al., 2019). But specific research on the usage of mutant sorghum as a food ingredient was still little done. Suarni (2017) reports the nutritional content and the tannins in the seeds and flour of several varieties of sorghum. Human (2010) report several chemical characteristics of mutant sorghum and conventional sorghum.

Some of the main nutrients in sorghum seeds as food ingredients are protein, total carbohydrate, fiber, and fat. Other elements that must be known are starch, dissolved protein, and reducing sugar. Starch (or amylum) is a complex carbohydrate that does not dissolve in water. It is composed of amylose and amylopectin in diverse compositions. Amylose gives it its hard quality while amylopectin causes its sticky quality. A dissolved protein is an oligopeptide or amino acid that is easily absorbed by the digestive system whereas total protein is a measurement of the nitrogen (or $\mathrm{N}$ ) content in the material. Reducing sugars such as glucose and fructose belong to a class of carbohydrates that can reduce electron-accepting compounds, for example. All monosaccharides (such as glucose, fructose, and galactose) and disaccharides (such as lactose and maltose) except sucrose and starch are included as reducing sugars (Winarno, 2008). 
Setiarto et al. (2016) reported that sorghum seeds could be processed into flour and become beneficial as a material to substitute for wheat flour. Sorghum is known to have no gluten so that sorghum flour is appropriate for consumption by gluten-allergic consumers or celiac sufferers (Schober et al., 2007). The constraint faced in the utilization of sorghum is the low digestibility of the protein in it and the presence of tannin compounds that affect the sensory aspect (sorghum being unpleasant in smell and taste) so that it is uncomfortable to consume. Sorghum protein is considered having a low quality food material because it does not contain lysine amino acid and has little threonine and tryptophan amino acids. Sorghum protein also difficult to digest because the protein is stored in protein bodies that remain intact during cooking (Suarni and Singgih, 2002; Sirappa, 2003).

Some efforts to improve the productivity of sorghum plants have already been done. They are such efforts as using superior varieties, fertilization and setting an optimum planting distance. One of the initiatives that need to be done is giving a supply of nitrogen fertilizer. All this time, urea (or $\mathrm{NH}_{2} \mathrm{CONH}_{2}$ ) is a source of $\mathrm{N}$ of the highest level in solid form and is the most important $\mathrm{N}$ fertilizer. This fertilizer can also increase the magnitude of protein content in plants and it can be also used for almost all types of plants, starting from food crops through to horticulture and plantation crops (Patola, 2008). Amujoyegbe et al. (2007) reported the effect of organic and inorganic fertilizers on sorghum chlorophyll content. Keskin et al. (2005) state that the addition of urea and urea molasses could improve the quality of sorghum plant silage.

The standard for sorghum flour quality is not yet available in Indonesia so that anyone concerned still refers to the Codex Standard 173-1989 (FAO, 1995). Working together with the Ministry of Agriculture, The National Nuclear Energy Agency of Indonesia (also known as Badan Tenaga Nuklir Nasional or BATAN, for short) has released three superior sorghum varieties given respectively the names of Pahat (short for Pangan Sehat, which means 'Healthy Food'), Samurai-1, and Samurai-2 (with Samurai being somehow abbreviated from Sorghum Mutan Radiasi, which means 'Radiation Mutant Sorghum'). Samurai-1 and Samurai-2 come from the seeds of the Pahat variety which are irradiated at a dose of $300 \mathrm{~Gy}$. The Pahat variety has the advantages, among others, of being able to adapt to the environment on dry land and marginal land (tolerating, in being grown, land with high soil acidity), of being low in tannin content (which is $0.012 \%$ in concentration), of the plant having semi-short stems (158 cm long), and of being potential as a food and animal feed resource. The Samurai-1 plant has a high sugar concentration in the trunk so that it is recommended as a source of bioenergy. Meanwhile, the Samurai-2 plant has the potential of being developed in the food field and its leaves are also good for livestock feed (Wahyono et al., 2014; BATAN, 2016)

Based on the above reasoning, the purpose of the research was to determine the influence of various doses of urea fertilizer administration on the chemical characteristics (ash, total protein, amylum, dissolved protein, reducing sugar, and tannin contents) of mutant sorghum grain varieties called Samurai-1, Samurai-2, and Pahat as food ingredients. It was expected that from this research information about the potential of mutant sorghum seed as a food ingredient would be obtained.

\section{Materials and methods}

\subsection{Location}

This research was conducted at the Experimental Garden of the Research Unit for Natural Product Technology, Indonesian Institute of Sciences (also known as Balai Penelitian Teknologi Bahan Alam Lembaga Ilmu Pengetahuan Indonesia or BPTBA LIPI, for short), Gunungkidul, Yogyakarta, located at the coordinates of $07^{\circ} 55^{\prime} 17.3^{\prime \prime}$ South Latitude and $110^{\circ} 34^{\prime}$ 35.7" East Longitude and having a tropical climate with 2,198 rainfalls/year with an average of 187 days/year of rainfalls.

\subsection{Materials}

The materials used consisted of mutant sorghum seed varieties of Pahat, Samurai-1, and Samurai-2, urea fertilizer. $\mathrm{CuSO}_{4}$, citric acid, sodium bicarbonate $\left(\mathrm{NaHCO}_{3}\right)$, sodium thiosulfate $\left(\mathrm{Na}_{2} \mathrm{~S}_{2} \mathrm{O}_{3}\right)$, glucose, sodium sulphate, sodium potassium tartrate (also known as Rochelle salt), ammonium molybdate, disodium hydrogen arsenate, bovine serum albumin (or BSA, for short), tannic acid, Folin Ciocalteau reagent, and aquadest (distilled water).

\subsection{Land preparation and planting}

The preparation includes land excavation and demolition and making planting plots. The planting was done by first digging suitable planting holes in the soil, each of which was then filled with four sorghum seeds and then filled back in with soil. The distance between any two planting holes nearest each other was according to a $40 \times 40 \mathrm{~cm}$ rectangular planting grid (Figure 1). The doses of urea fertilizer were $0 \mathrm{~kg} / \mathrm{ha}, 30 \mathrm{~kg} / \mathrm{ha}, 60 \mathrm{~kg} / \mathrm{ha}$, and $90 \mathrm{~kg} / \mathrm{ha}$, given to ten days old plants in accordance with treatment. The urea fertilizer was given at a distance 
of $+5 \mathrm{~cm}$ from any nearest planting hole. Plant thinning was done when the plants were ten days old, leaving only the two best plants in each planting hole. Plant watering was done every day until the plants reached field capacity. Weeding was done for weed control. The care given during the study included weeding of weeds and replanting when there were plants from the stock of seeds that stopped growing. The ripe sorghum panicles were covered with a plastic bag to prevent bird attacks. The sorghum seed harvest was carried out at the age of 100 days (Winata et al., 2014).

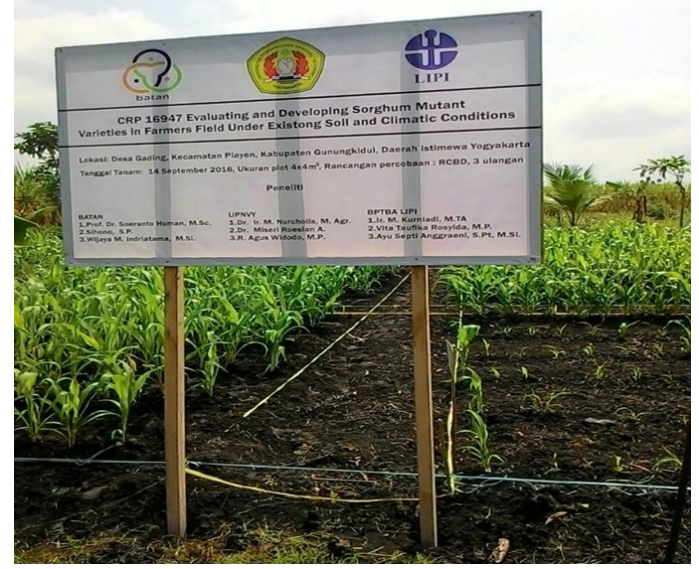

Figure 1. Cultivation of mutant sorghum varieties Samurai-1, Samurai-2 and Pahat at the BPTBA LIPI Experimental Garden in Gunungkidul Yogyakarta

\subsection{Sample preparation}

The sorghum panicles were dried after harvest in the open air under the sun and then threshing was done. The sorghum seeds were separated from the debris and other foreign matter and then dried in an oven at a temperature of $60^{\circ} \mathrm{C}$ for $16 \mathrm{hrs}$. Then grinding with a pin disk mill was done to the dried seeds until we get an 80-mesh size of sorghum flour sample (Setiarto and Widhyastuti, 2016).

\subsection{Nutritional value of sorghum flour}

The parameters for testing the nutritional value of sorghum flour include the moisture content, measured by using the thermogravimetric method, the ash content, measured by using the dry ashing method, the total protein content, measured by using the Kjeldahl method, the starch content, measured by using the Luff Schoorl method (Latimer, 2016; Abe-Inge et al., 2018), the reducing sugar content, measured by using the NelsonSamogy method, the dissolved protein content, measured by using the Lowry method (Sudarmadji et al., 1997), and the tannin levels, measured by using the Folin Ciocalteu method (Chaovanalikit and Wrolstad, 2004).

\subsection{Design of the experiment}

The research concerned here was organized by using the completely randomized factorial design employing two factors with three replications. The first factor was mutant sorghum variety (represented by V) which was divided into three, namely, V1 representing Samurai-1, V2 representing Samurai-2, and V3 representing Pahat. The second factor is the dose of urea fertilizer which was divided into one control and three treatments, namely, $\mathrm{N} 1$ representing a urea dose of $0 \mathrm{~kg} / \mathrm{ha}, \mathrm{N} 2$ representing a urea dose of $30 \mathrm{~kg} / \mathrm{ha}, \mathrm{N} 3$ representing a urea dose of $60 \mathrm{~kg} / \mathrm{ha}$, and N4 representing a urea dose of $90 \mathrm{~kg} / \mathrm{ha}$. The data obtained were analyzed by using analysis of variance (also known as ANOVA) and, when there was a real influence, continuing with Duncan's New Multiple Range Test with $\alpha$ of $5 \%$ (Kurniadi et al., 2019).

\section{Results and discussion}

\subsection{The effect of urea on ash content}

The ash from a food material shows the extent of minerals contained in food ingredients such as calcium, phosphorus, and iron. The results of the test of the ash content are presented in Table 1.

Table 1. The analysis result of mutant sorghum flour ash content $(\%)$

\begin{tabular}{cccc}
\hline \multirow{2}{*}{$\begin{array}{c}\text { Urea dose } \\
(\mathrm{kg} / \mathrm{Ha})\end{array}$} & \multicolumn{3}{c}{ Sorghum Variety } \\
\cline { 2 - 4 } & Samurai-1 & Samurai-2 & Pahat \\
\hline 0 & $1.73 \pm 0.25^{\mathrm{aA}}$ & $1.33 \pm 0.06^{\mathrm{aA}}$ & $1.7 \pm 0.1^{\mathrm{aA}}$ \\
30 & $1.65 \pm 0.26^{\mathrm{aA}}$ & $1.25 \pm 0.17^{\mathrm{aA}}$ & $1.64 \pm 0.05^{\mathrm{aA}}$ \\
60 & $1.69 \pm 0.27^{\mathrm{aA}}$ & $1.32 \pm 0.01^{\mathrm{aA}}$ & $1.87 \pm 0.06^{\mathrm{aA}}$ \\
90 & $2 \pm 0.08^{\mathrm{aB}}$ & $1.03 \pm 0.05^{\mathrm{aA}}$ & $1.42 \pm 0.03^{\mathrm{aAB}}$ \\
\hline
\end{tabular}

Values are expressed as mean \pm SD. Values with different lowercase superscript within the same column and different uppercase superscript within the same row indicate significant difference using Duncan's standard test at $\alpha=5 \%$.

Based on Table 1, it is shown that there is a significant effect on the three varieties at the time of each application of urea fertilizer for each different dose. Sorghum flour contains such minerals as calcium, phosphorus, and iron (Suarni and Singgih, 2002). USDA (2020) states that the maximum ash content of sorghum flour is $1.98 \%$; the test results show that the ash content of the flour made from the three varieties for each application of urea fertilizer and without urea fertilizer is still below 1.98\%. Codex Alimentarious (2007) requires a maximum ash content of $3.5 \%$. This shows that the three sorghum flour varieties meet the requirements for good sorghum flour. The ash content is a parameter of the purity of the products, influenced by elements of minerals in the food ingredients. In addition, ash is an oily residue from the combustion process of organic material and each component is generally a smooth and white particle (Winarno, 2008). 


\subsection{The effect of urea on protein content}

The compounds that have a role in the formation of protein in sorghum are the nutrients Nitrogen $(\mathrm{N})$ and Potassium (K). Nitrogen is a component of DNA and RNA in every plant cell. Nitrogen is mostly needed by plants and is often more efficient than other nutrients. Potassium has a role in the activity of plant biochemical functions by, for example, activating various enzymes and co-enzymes, forming protein, and regulating the opening and closing of stomata so that plants can avoid the effects of drought as well as increase resistance to pests and diseases and do not easily collapse (Syafrudin, 2013). The results of testing the effect of urea on total protein content are presented in Table 2 .

Table 2. Analysis results of total protein content from mutant sorghum grain (\%)

\begin{tabular}{cccc}
\hline \multirow{2}{*}{$\begin{array}{c}\text { Urea dose } \\
(\mathrm{kg} / \mathrm{Ha})\end{array}$} & \multicolumn{3}{c}{ Sorghum Variety } \\
\cline { 2 - 4 } & Samurai-1 & Samurai-2 & Pahat \\
\hline 0 & $6.67 \pm 0.03^{\mathrm{aA}}$ & $5.38 \pm 0.03^{\mathrm{aA}}$ & $7.53 \pm 0.85^{\mathrm{aA}}$ \\
30 & $7.34 \pm 0.05^{\mathrm{aA}}$ & $5.4 \pm 0.05^{\mathrm{aA}}$ & $6.63 \pm 0.17^{\mathrm{aA}}$ \\
60 & $7.71 \pm 0.03^{\mathrm{aA}}$ & $5.46 \pm 0.05^{\mathrm{aA}}$ & $6.68 \pm 0.07^{\mathrm{aA}}$ \\
90 & $7.9 \pm 0.08^{\mathrm{aA}}$ & $4.29 \pm 0.04^{\mathrm{aB}}$ & $6.43 \pm 0.58^{\mathrm{aAB}}$ \\
\hline
\end{tabular}

Values are expressed as mean \pm SD. Values with different lowercase superscript within the same column and different uppercase superscript within the same row indicate significant difference using Duncan's standard test at $\alpha=5 \%$.

Based on Table 2, it is seen that the highest protein content (i.e., 7.9\%) is in the Samurai-1 variety with a urea fertilizer dose of $90 \mathrm{~kg} / \mathrm{ha}$. The higher the urea dose, the more significant the protein content. Meanwhile, the lowest (i.e., $4.29 \%$ ) is in the Samurai-2 variety. In the Samurai-1 and Samurai-2 varieties, there is a significant effect of urea use on protein content but it is different for the Pahat variety. These results differ from those reported by Human (2010). The mutant sorghum of the Samurai-1, Samurai-2, and Pahat varieties cultivated in the Banyuwangi and Merauke areas of Papua have a higher protein content, i.e., $12.80 \%, 12.55 \%$, and $12.07 \%$, respectively. This difference is likely to be due to several different factors, such as soil condition and rainfall.

According to Susila (2005), protein levels are influenced by genetic and environmental factors. The protein content of sorghum varies considerably. The fluctuation in sorghum protein content, in general, also affects the composition of its essential amino acids. According to the quality requirements of the Codex Standard 173-1989, the protein content for sorghum with an $\mathrm{N}$ minimum value of 25 is $8.5 \%$. From the results of the data in Table 3, it can be said that the protein contents of the three varieties of sorghum have not met the requirements because the levels are below $8.5 \%$.

Ruan et al. (2016) explained that the final product of urea is in the form of $\mathrm{NH}_{4}^{+}$and $\mathrm{NO}_{3}{ }^{-}$ions for absorption by plants. The more $\mathrm{N}$ available to plants, the higher the production of sorghum protein. Althwab et al. (2015) have reported that the protein content of sorghum of several varieties in Indonesia ranges from $7 \%$ to $15 \%$. The protein content of sorghum seed flour can be increased by the fermentation process using L. plantarum and $S$. cereviseae microbes so that it can become a source of functional protein (Setiarto and Widhyastuti, 2016; Kurniadi et al., 2019).

\subsection{The effect of urea on amylum content}

The level of amylum (or starch) is an important parameter in flour products because it influences the determination of the structure, texture, consistency, and appearance of food products. According to Palavecino et al. (2016), amylum is a form of the main carbohydrate deposit in sorghum, consisting of amylose, which is a glucose polymer of the straight-chain (i.e., without branches) and amylopectin, which is a glucose polymer that has branches. The digestive process of amylum shows the ability of hydrolysis by pancreatic enzymes and determines the energy content available in Cerealia. The test results of the level of amylum are presented in Table 3.

Table 3. Analysis results of amylum content from mutant sorghum grain (\%)

\begin{tabular}{cccc}
\hline \multirow{2}{*}{$\begin{array}{c}\text { Urea dose } \\
(\mathrm{kg} / \mathrm{Ha})\end{array}$} & \multicolumn{3}{c}{ Sorghum Variety } \\
\cline { 2 - 4 } & Samurai-1 & Samurai-2 & Pahat \\
\hline 0 & $13.26 \pm 0.01^{\mathrm{aA}}$ & $11.4 \pm 1.08^{\mathrm{aAB}}$ & $6.42 \pm 0.46^{\mathrm{aB}}$ \\
30 & $13.14 \pm 0.05^{\mathrm{aA}}$ & $12.62 \pm 0.44^{\mathrm{aA}}$ & $8.11 \pm 0.01^{\mathrm{aA}}$ \\
60 & $13.11 \pm 0.02^{\mathrm{aA}}$ & $12.39 \pm 0.52^{\mathrm{aA}}$ & $10.08 \pm 0.12^{\mathrm{aA}}$ \\
90 & $14.52 \pm 0.07^{\mathrm{aA}}$ & $8.86 \pm 0.18^{\mathrm{bA}}$ & $10.18 \pm 0.1^{\mathrm{aA}}$ \\
\hline
\end{tabular}

Values are expressed as mean \pm SD. Values with different lowercase superscript within the same column and different uppercase superscript within the same row indicate significant difference using Duncan's standard test at $\alpha=5 \%$.

Based on Table 3, the highest starch content was found in the mutant sorghum of the Samurai-1 variety with a urea fertilizer dose of $90 \mathrm{~kg} / \mathrm{ha}$ and the lowest was in the mutant sorghum of the Pahat variety with a urea fertilizer dose of $0 \mathrm{~kg} / \mathrm{ha}$. The effect of urea fertilizer doses was significantly different on the starch content of the Pahat variety but not on that of the Samurai-1 and Samurai-2 varieties. Too low a starch content is not expected in flour-starch products. Carbohydrates consist of monosaccharides, disaccharides, polysaccharides, and oligosaccharides. Starch is included as a polysaccharide if the starch content that has been analyzed ranges from $8.68 \%$ to $12.26 \%$, the remaining $56.4 \%$ is another type 
of carbohydrate. Sorghum has lower digestibility of starch; steaming, pressure processing, flaking, puffing, or size reduction could increase the digestibility (Susila, 2005; Palavecino et al., 2016). Sorghum is a food source that has a starch content ranging from $65 \%$ to $80 \%$ (Althwab et al., 2015).

Low levels of starch in sorghum plants can be caused by the absence of additional fertilizers. According to Gardner et al. (2005), if the fertilizer dose is added accordingly, it will affect the vegetative growth of sorghum well so that the food reserves produced will be high in level and can be allocated for seed filling. In addition, the starch content in sorghum can be influenced by environmental factors such as soil, air, sunlight, and genetics (Suarni and Subagio, 2013).

\subsection{The effect of urea on reducing sugar content}

Included in the group of reducing sugars are glucose, mannose, fructose, lactose, and maltose. The reduced sugars in sorghum are glucose and maltose. The results of testing the effect of urea fertilizer on reducing sugar levels are presented in Table 4.

Table 4. Analysis results of reducing sugar content from mutant sorghum grain (\%)

\begin{tabular}{cccc}
\hline \multirow{2}{*}{$\begin{array}{c}\text { Urea dose } \\
(\mathrm{kg} / \mathrm{Ha})\end{array}$} & \multicolumn{3}{c}{ Sorghum Variety } \\
\cline { 2 - 4 } & Samurai-1 & Samurai-2 & Pahat \\
\hline 0 & $2.14 \pm 0.08^{\mathrm{aA}}$ & $0.98 \pm 0.02^{\mathrm{aA}}$ & $1.41 \pm 0.13^{\mathrm{aA}}$ \\
30 & $2.02 \pm 0.06^{\mathrm{aA}}$ & $0.83 \pm 0.01^{\mathrm{aA}}$ & $1.53 \pm 0.04^{\mathrm{aA}}$ \\
60 & $2.49 \pm 0.04^{\mathrm{aB}}$ & $0.44 \pm 0.03^{\mathrm{aA}}$ & $1.53 \pm 0.09^{\mathrm{aAB}}$ \\
90 & $1.82 \pm 0.02^{\mathrm{aA}}$ & $0.72 \pm 0.01^{\mathrm{aA}}$ & $1.51 \pm 0.21^{\mathrm{aA}}$ \\
\hline
\end{tabular}

Values are expressed as mean $\pm \mathrm{SD}$. Values with different lowercase superscript within the same column and different uppercase superscript within the same row indicate significant difference using Duncan's standard test at $\alpha=5 \%$.

Based on Table 4, the highest-level content of reducing sugar is of the Samurai-1 variety with the dose of urea fertilizer being $60 \mathrm{~kg} / \mathrm{ha}$ and the lowest is of the Samurai-2 variety with the dose of urea fertilizer being $60 \mathrm{~kg} / \mathrm{ha}$. There is no significant influence from the addition of urea dose on the reducing sugar content of the Samurai-2 and Pahat varieties but there is significant influence from the addition of urea fertilizer doses of 30 , 60 , and $90 \mathrm{~kg} / \mathrm{Ha}$ on the reducing sugar content of the Samurai-1 variety.

Urea was known as a nitrogen source for plants. During the utilization of nitrogen-rich material, the plant needs to build nodules on its root. Gibson (1966) reported that the formation of nodules need more carbohydrate. Rufty et al. (1988) also revealed that nitrogen exposure increased leaf dry weight and starch production.

\subsection{The effect of urea on dissolved protein content}

The value of the dissolved protein content is lower than that of the total protein content. The results of the dissolved protein content test are presented in Table 5.

Table 5. Analysis results of dissolved protein from mutant sorghum grain $(\%)$

\begin{tabular}{cccc}
\hline $\begin{array}{c}\text { Urea dose } \\
(\mathrm{kg} / \mathrm{Ha})\end{array}$ & \multicolumn{3}{c}{ Sorghum Variety } \\
\cline { 2 - 4 } & Samurai-1 & Samurai- 2 & Pahat \\
\hline 0 & $1.66 \pm 0.09^{\mathrm{aA}}$ & $0.76 \pm 0.13^{\mathrm{aA}}$ & $1.26 \pm 0.11^{\mathrm{aA}}$ \\
30 & $1.68 \pm 0.08^{\mathrm{aA}}$ & $0.39 \pm 0.18^{\mathrm{aA}}$ & $1.36 \pm 0.02^{\mathrm{aA}}$ \\
60 & $2.19 \pm 0.41^{\mathrm{aA}}$ & $0.41 \pm 0.23^{\mathrm{aA}}$ & $1.31 \pm 0.08^{\mathrm{aA}}$ \\
90 & $2.38 \pm 0.28^{\mathrm{aA}}$ & $0.61 \pm 0.09^{\mathrm{aA}}$ & $1.29 \pm 0.07^{\mathrm{aA}}$ \\
\hline
\end{tabular}

Values are expressed as mean \pm SD. Values with different lowercase superscript within the same column and different uppercase superscript within the same row indicate significant difference using Duncan's standard test at $\alpha=5 \%$.

Based on Table 5, the highest dissolved protein content, namely, $2.38 \%$, was in the Samurai-1 sorghum variety with the urea fertilizer dose of $90 \mathrm{~kg} / \mathrm{ha}$ and the lowest, namely, $0.39 \%$, was in the Samurai-2 sorghum variety with the urea fertilizer dose of $30 \mathrm{~kg} / \mathrm{ha}$. In the Samurai-1 variety, the higher the urea dose, the greater the dissolved protein content; a significant difference in effect was seen among the urea doses of 30,60 , and 90 $\mathrm{kg} / \mathrm{ha}$. In the Samurai-2 and Pahat varieties, urea addition was not significantly different in effect on the dissolved protein content.

The difference in dissolved protein content can occur because the solubility of protein is influenced by several factors such as raw material, processing condition, $\mathrm{pH}$, ionic strength, and the presence of other ingredients (Kurniadi et al., 2013). Losing the $\mathrm{N}$ element is the same as being without the addition of fertilizer-this condition is due to the addition of urea fertilizer, which contains $\mathrm{N}$, into sorghum plants. The $\mathrm{N}$ element in plant tissue is a constituent component of many essential compounds, such as amino acids, proteins, and an enzyme builder (Ruan et al., 2016).

\subsection{The effect of urea on tannin levels}

Tannins are very complex organic substances that are widely available in various plants and consist of phenolic compounds. Generally, tannins are found in such plant parts as the bark, stems, leaves, and fruit (Pizzi, 2008). The results of the sorghum flour tannin content test are presented in Table 6 .

Based on Table 6, overall, there is no significant effect of urea fertilization on the tannin content of sorghum flour. The lowest tannin content, which was between 0.30 and $0.34 \%$, was of the Pahat variety and the highest, which was between 0.55 and $0.70 \%$, was of the Samurai-1 variety. However, in relation to a certain 
case, Human (2010) reported as follows: the tannin contents in the mutant sorghum varieties of Samurai-1, Samurai-2, and Pahat are, respectively, $0.030 \%, 0.016 \%$, and $0.012 \%$. According to the Codex Standard 173-1989, among the quality requirements for sorghum flour is that the maximum tannin content is $0.3 \%$. At low levels, sorghum tannins react as antioxidants but in high concentrations, they react as antinutrients. Widowati (2010) states that the tannin content of whole sorghum seeds is $3.11 \%$ and, after being processed into sorghum flour, the tannin content can decrease to $0.66 \%$.

Table 6. Analysis results of tannin content from mutant sorghum grain $(\%)$

\begin{tabular}{cccc}
\hline $\begin{array}{c}\text { Urea dose } \\
(\mathrm{kg} / \mathrm{Ha})\end{array}$ & \multicolumn{3}{c}{ Sorghum Variety } \\
\cline { 2 - 4 } & Samurai-1 & Samurai-2 & Pahat \\
\hline 0 & $0.55 \pm 0.03^{\mathrm{aA}}$ & $0.36 \pm 0.04^{\mathrm{aA}}$ & $0.31 \pm 0.01^{\mathrm{aA}}$ \\
30 & $0.57 \pm 0.03^{\mathrm{aA}}$ & $0.44 \pm 0.1^{\mathrm{aA}}$ & $0.37 \pm 0.01^{\mathrm{aA}}$ \\
60 & $0.61 \pm 0.02^{\mathrm{aA}}$ & $0.35 \pm 0.01^{\mathrm{aA}}$ & $0.36 \pm 0.02^{\mathrm{aA}}$ \\
90 & $0.7 \pm 0.05^{\mathrm{aA}}$ & $0.35 \pm 0.01^{\mathrm{aA}}$ & $0.35 \pm 0.01^{\mathrm{aA}}$ \\
\hline
\end{tabular}

Values are expressed as mean \pm SD. Values with different lowercase superscript within the same column and different uppercase superscript within the same row indicate significant difference using Duncan's standard test at $\alpha=5 \%$.

Red to brown sorghum seeds contain higher tannins than white sorghum ones (Suarni and Singgih, 2002). The tannin content in sorghum is concentrated in the outermost layer of skin; it is proven that the sorghum fusion stage reduces the tannin content by $75 \%$, from the range of $1.82-3.98 \%$ to that of $0.36-1.72 \%$, depending on the variety (Suarni and Patong, 2002). Based on the results and discussion above, the sorghum seed flour of the three varieties has met the standard quality parameters determined by the Codex Standard 173-1989 (WHO and FAO, 2007) as the food with the best quality is the Samurai-1 variety.

\section{Conclusion}

The use of urea fertilizer significantly influences the levels of ash, amylum, reducing sugar, and dissolved protein in the mutant sorghum bean flour variety named Samurai-1 but it does not significantly influence those in the varieties named Samurai-2 and Pahat. The urea fertilizer dose of $90 \mathrm{~kg} / \mathrm{Ha}$ gives the best results concerning the chemical composition of the three varieties of mutant sorghum grain. Chemically, the three varieties of mutant sorghum flour qualify as quality food with materials of the best quality. The very best of the three, however, is the Samurai-1 variety with total protein content of $7.90 \%$, starch content of $14.51 \%$, dissolved protein content of $2.38 \%$, reducing sugar content of $2.88 \%$, and tannin content of $0.70 \%$.

\section{Conflict of interest}

The authors declare that there are no conflicts of interest regarding the publication of this paper.

\section{Acknowledgments}

The research concerned here is a result of cooperation between the Faculty of Agriculture of UPN "Veteran" Yogyakarta and the Research Unit for Natural Product Technology of the Indonesian Institute of Sciences (also known as BPTBA LIPI). The authors express their appreciation of the Faculty of Agriculture of UPN "Veteran" Yogyakarta and BPTBA LIPI, Yogyakarta, for the cooperation.

\section{References}

Abe-Inge, V., Agbenorhevi, J.K., Kpodo, F.M. and Adzinyo, O.A. (2018). Effect of different drying techniques on quality characteristics of African palmyra palm (Borassus aethiopum) fruit flour. Food Research, 2(4), 331-339. https://doi.org/10.26656/ fr.2017.2(4).050

Althwab, S., Carr, T.P., Weller, C.L., Dweikat, I.M. and Schlegel, V. (2015). Advances in grain sorghum and its co-products as a human health promoting dietary system. Food Research International, 77(Part 3), 349-359.

https://doi.org/10.1016/

j.foodres.2015.08.011

Amujoyegbe, B.J., Opabode, J.T. and Olayinka, A. (2007). Effect of organic and inorganic fertilizer on yield and chlorophyll content of maize (Zea mays L.) and sorghum Sorghum bicolour (L.) Moench. African Journal of Biotechnology, 6(16), 1869-1873. https://doi.org/10.5897/ajb2007.000-2278

Awadalkareem, A.M., Mustafa, A.I. and El Tinay, A.H. (2008). Protein, mineral content and amino acid profile of sorghum flour as influenced by soybean protein concentrate supplementation. Pakistan Journal of Nutrition, 7(3), 475-479. https:// doi.org/10.3923/pjn.2008.475.479

Awika, J.M. and Rooney, L.W. (2004). Sorghum phytochemicals and their potential impact on human health. Phytochemistry, 65(9), 1199-1221. https:// doi.org/10.1016/j.phytochem.2004.04.001

BATAN. (2016). BATAN Kembangkan Tanaman Penghasil Bioenergi. Retreived from BATAN website: http://www.batan.go.id/index.php/id/ publikasi2/pressreleases. [In Bahasa Indonesia].

Chaovanalikit, A. and Wrolstad, R.E. (2004). Total Anthocyanins and Total Phenolics of Fresh and Processed Cherries and Their Antioxidant Properties. Journal of Food Science, 69(1), FCT67-FCT72. https://doi.org/10.1111/j.1365-2621.2004.tb17858.x 
Earp, C.F., McDonough, C.M. and Rooney, L.W. (2004). Microscopy of pericarp development in the caryopsis of Sorghum bicolor (L.) Moench. Journal of Cereal Science, 39(1), 21-27. https://doi.org/10.1016/S0733 $-5210(03) 00060-2$

Gardner, F., Perace, R.B. and Mitchell, R.L. (2005). Fisiologi Tanaman Budidaya. Indonesia: UI Press. [In Bahasa Indonesia].

Gibson, A. (1966). The Carbohydrate Requirements for Symbiotic Nitrogen Fixation: A "Whole-Plant" Growth Analysis Approach. Australian Journal of Biological Sciences, 19(4), 499. https:// doi.org/10.1071/BI9660499

Human, S. (2010). Sorghum Breeding for Improved Drought Tolerance Using Induced Mutation with Gamma Irradiation. Indonesian Journal of Agronomy, 38(2), 95-99.

Keskin, B., Yilmaz, I.H., Karsli, M.A. and Nursoy, H. (2005). Effects of urea or urea plus molasses supplementation to silages with different sorghum varieties harvested at the milk stage on the quality and in vitro dry matter digestibility of silages. Turkish Journal of Veterinary and Animal Sciences, 29(5), 1143-1147.

Kurniadi, M., Arysad, M.F., Sari, A.M., Nurhayati, R. and Wiyono, T. (2019). The effect of fermentation duration and starter concentration on physicochemical properties of modified sorghum flour by $\{$ Lactobacillus\} plantarum $\{$ FNCC 0027. Food Research, 3(5), 441-447. https:// doi.org/10.26656/fr.2017.3(5).098

Kurniadi, M., Martina, A., Faris, F. and Damayanti, E. (2013). Karakteristik Fisikokimia Tepung Biji Sorghum (Sorghum bicolor L.) Terfermentasi Bakteri Asam Laktat Lactobacilllus acidophilus. Agritech, 33(3), 288-295. https://doi.org/10.22146/ agritech.9550

Latimer, G.W. (2016). Official Methods of Analysis of AOAC International. Vol. 2, $20^{\text {th }}$ ed. USA: AOAC International.

Palavecino, P.M., Penci, M.C., Calderón-Domínguez, G. and Ribotta, P.D. (2016). Chemical composition and physical properties of sorghum flour prepared from different sorghum hybrids grown in Argentina. Starch/Starke, 68(11-12), 1055-1064. https:// doi.org/10.1002/star.201600111

Patola, E. (2008). Analisis Pengaruh Dosis Pupuk Urea Dan Jarak Tanam Terhadap Produktivitas Jagung Hibrida P-21 (Zea mays L.). Jurnal Inovasi Pertanian, 7(1), 51-65. [In Bahasa Indonesia].

Pizzi, A. (2008). Tannins: Major Sources, Properties and Applications. In Belgacem, M.N. and Gandini, A.
(Eds.) Monomers, Polymers and Composites from Renewable Resources, p. 179-199. USA: Elsevier. https://doi.org/10.1016/B978-0-08-045316-3.000089

Ruan, L., Wei, K., Wang, L., Cheng, H., Zhang, F., Wu, L., Bai, P. and Zhang, C. (2016). Characteristics of NH4+ and NO3- fluxes in tea (Camellia sinensis) roots measured by scanning ion-selective electrode technique. Scientific Reports, 6(1), 38370. https:// doi.org/10.1038/srep38370

Rufty, T.W., Huber, S.C. and Volk, R.J. (1988). Alterations in Leaf Carbohydrate Metabolism in Response to Nitrogen Stress. Plant Physiology, 88 (3), 725-730. https://doi.org/10.1104/pp.88.3.725

Schober, T.J., Bean, S.R. and Boyle, D.L. (2007). Gluten -free sorghum bread improved by sourdough fermentation: Biochemical, rheological, and microstructural background. Journal of Agricultural and Food Chemistry, 55(13), 5137-5146. https:// doi.org/10.1021/jf0704155

Setiarto, R.H.B. and Widhyastuti, N. (2016). Reduction of Tannin and Phytic Acid on Sorghum Flour by using Fermentation of Rhizopus oligosporus, Lactobacillus plantarum and Saccharomyces cerevisiae. Jurnal Ilmu-Ilmu Hayati, 15(2), 107-206. https://doi.org/10.1016/j.amjcard.2005.03.104

Sirappa, M.P. (2003). Prospek pengembangan sorgum di indonesia sebagai komoditas alternatif untuk pangan, pakan, dan industri. Jurnal Litbang Pertanian, 22(4), 133-140. [In Bahasa Indonesia].

FAO. (1995). Codex Standard for Wheat Flour (Codex Standard 152-1985). USA: FAO.

Suarni and Patong. (2002). Chemical Composition of Sorghum Flour for Wheat Flour Substitution (in Indonesian). Penelitian Pertanian Tanaman Pangan, 21(1), 43-47.

Suarni. (2017). Peranan Sifat Fisikokimia Sorgum dalam Diversifikasi Pangan dan Industri serta Prospek Pengembangannya. Jurnal Penelitian Dan Pengembangan Pertanian, 35(3), 99-110. https:// doi.org/10.21082/jp3.v35n3.2016.p99-110. [In Bahasa Indonesia].

Suarni and Singgih, S. (2002). Karakteristik Sifat Fisik dan Komposisi Kimia Beberapa Varietas/Galur Biji Sorgum. Jurnal Stigma, 10(2), 127-130. [In Bahasa Indonesia].

Suarni and Subagio, H. (2013). The Potency of Corn and Sorghum Development for Functional Food Material (in Indonesian). Jurnal Penelitian dan Pengembangan Pertanian, 32(2), 99-110.

Sudarmadji, S., Haryono, B. and Suhardi. (1997). Prosedur Analisa untuk Bahan Makanan dan 
Pertanian. 4th ed. Indonesia: Liberty. [In Bahasa Indonesia].

Susila, B.A. (2005). Keunggulan mutu gizi dan sifat fungsional Sorgum (Sorghum Vulgare). Prosiding Seminar Nasional Teknologi Inovatif Pascapanen untuk Pengembangan Industris Berbasis Pertaning, 527-534. [In Bahasa Indonesia].

Syafrudin. (2013). Pemupukan Tanaman Gandum. Indonesia: Balai Penelitian Tanaman Serealia. [In Bahasa Indonesia].

USDA. (2020). Sorghum bicolor (L.) Moench ssp. arundinaceum (Desv.) de Wet and Harlan common wild sorghum. https://plants.usda.gov/core/profile? symbol=SOBIA

Wahyono, T., Astuti, D.A., Wiryawan, K.G. and Sugoro, I. (2014). Pengujian Ransum Kerbau Berbahan Baku Sorgum Sebagai Sember Serat Secara In Vitro dan In Sacco. Jurnal Ilmiah Aplikasi Isotop Dan Radiasi, 10(2), 113-126. [In Bahasa Indonesia].

WHO and FAO. (2007). CODEX Alimentarius Cereals, pulses, legumes and vegetable proteins (CODEX STAN 171-1989). USA: WHO and FAO.

Widowati, S. (2010). Karakteristik Mutu Gizi Dan Diversifikasi Pangan Berbasis Sorgum (Sorghum vulgare). Pangan, 19(4), 373-382. [In Bahasa Indonesia].

Winarno, F. (2008). Kimia Pangan Dan Gizi. Indonesia: Gramedia Pustaka Utama. [In Bahasa Indonesia].

Winata, N.A.S., Lukiwati, D.R. and Purbajanti, E.D. (2014). Kualitas Biji Sorgum Manis Varietas Numbu Dengan Pemberian Pupuk Sumber Fosfat yang Berbeda. Agrovivor, 7(1), 63-70. [In Bahasa Indonesia]. 